\title{
ПОВЫШЕНИЕ ДОЛГОВЕЧНОСТИ АВТОМОБИЛЬНЫХ ДОРОГ С ИСПОЛЬЗОВАНИЕМ НАНОСТРУКТУРИРОВАННЫХ АСФАЛЬТО-МИНЕРАЛЬНЫХ БЕТОНОВ
}

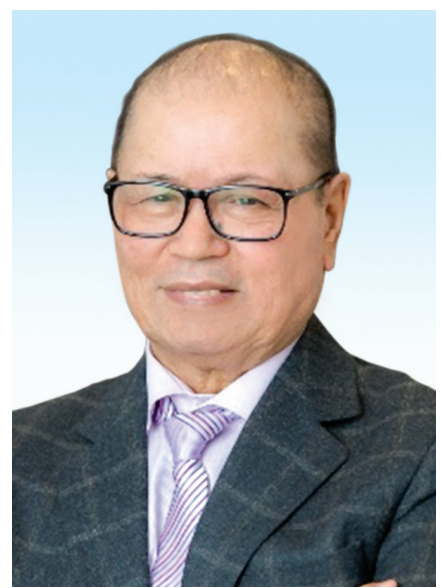

Б.А. АСМАТУЛАЕВ ${ }^{1 *}$, доктор технических наук, профессор, академический советник Национальной инженерной академии РК, директор по науке, https://orcid.org/0000-00015774-5423

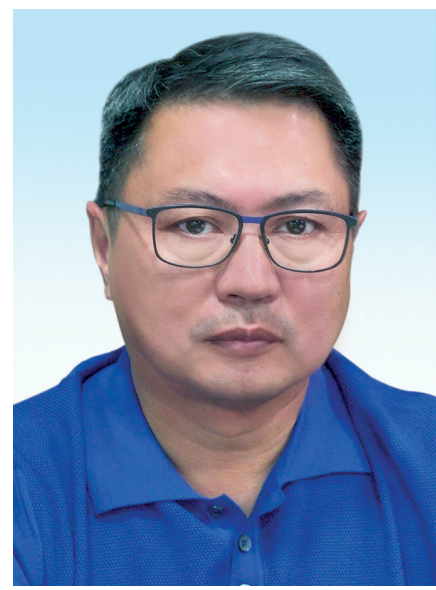

Р.Б. АСМАТУЛАЕВ ${ }^{2}$, кандидат технических наук директор, https://orcid.org/0000-00015531-6641

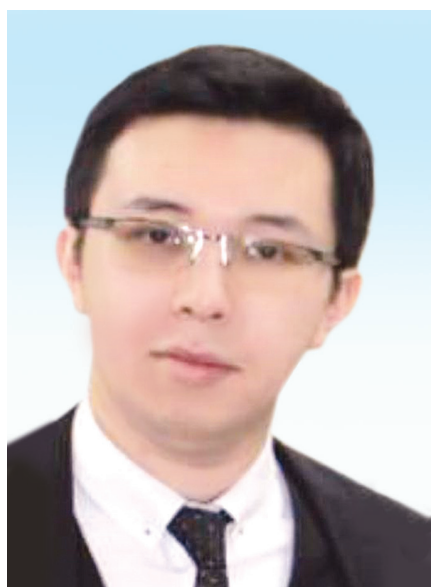

Н.Б. АСМАТУЛАЕВ ${ }^{1}$, докторант, магистр главный инженер, https://orcid.org/0000-00017562-7252

1 ТОО КАЗНИИПИ «ДОРТРАНС», Республика Казахстан, 050010, г. Алматы, ул. Гоголя 84a

2ТОО КАЗДОРИННОВАЦИЯ,

Республика Казахстан, 050031, г. Алматы, мкр. Баянауыл, 1

В начале нынешнего столетия выдвинуты новые требования для долговечных дорожных конструкций, в связи с повышением транспортных нагрузок на автомобильных дорогах в 2-3 раза. Приведены результаты фундаментальных, экспериментальных и практических исследований по разработке наноструктурированных асфальто-минеральных и дорожных нано бетонов, которые соответствуют этим требованиям. В результате многолетних научных исследований и мониторинга автомобильных дорог, впервые в Казахстане подтверждена эффрективность применения длительно (медленно) твердеющих вяжущих веществ, с преимущественным содержанием двух кальциевого силиката $\left(C_{2} S\right)$, при сопоставлении с высоко прочными портландцементами. При гидратации $\mathrm{C}_{2} \mathrm{~S}$, основными структурообзующими новообразованиями (более 60\%) являются гидросиликаты кальция C-S-H, имеющие нано размерные величины, поэтому такие материалы отнесены к наноструктурированным бетонам. Впервые в дорожной практике подтверждена эфрфрективность и справедливость применения теория о коллоидной структуре упрочне-

* Адрес для переписки. E-mail: boris-aisa@mail.ru 
ния на дорожных наноструктурированных асфральто-минеральных и дорожных бетонах, обладающих свойствами тиксотропии-самовосстановления и реопексии-упрочнения от действия транспортных и температурных нагрузок, в процессе эксплуатации автомобильных дорог. Долговечность асфальто-минеральных и дорожных бетонов обосновываются результатами выполненных фунндаментальных физико-химических исследований структуры белитового наноструктурирующего асфральтового вяжущего и белитового цементного камня. Достоверность которых подтверждена результатами испытаний бетонных образцов, длительно выдержанных при различных температурах в лабораторных условиях и кернов, высверленных из асфральто-минеральных и бетонных дорог. Прочность бетонов продолжает упрочняться в течение более 40 лет. Предполагается, что это путь к долговечным «римским бетонам».

КЛЮЧЕВЫЕ СЛОВА: автомобильные дороги,долговечность, наноструктурированные асфральто-минеральные и дорожные бетоны, фризико-химические исследования, асфральтовое вяжущее, цементный камень, структура, фризико-механические испытания, прочность.

\title{
НАНОҚҰРЫЛЫМДЫ АСФАЛЬТ-МИНЕРАЛДЫ БЕТОНДАРДЫ ПАЙДАЛАНА ОТЫРЫП, АВТОМОБИЛЬ ЖОЛДАРЫНЫҢ БEPIKTIГIH APTTЫPY
}

\begin{abstract}
Б.А. АСМАТУЛАЕВ ${ }^{1}$, техника ғылымдарының докторы, профессор, ҚР Ұлттық Инженерлік Академиясының академиялық кеңесшісі, ғылым жөніндегі директор ҚазҒЗ және ЖИ «Дортранс» ЖШС, https://orcid.org/0000-0001-5774-5423;

Р.Б. АСМАТУЛАЕВ ${ }^{2}$, техника ғылымдарының кандидаты директоры, https://orcid.org/00000001-5531-6641;
\end{abstract}

Н.Б. АСМАТУЛАЕВ ${ }^{1}$, докторант, магистрант, бас инженер, https://orcid.org/0000-0001-7562-7252

1 ТОО КАЗНИИПИ «ДОРТРАНС»,

Қазақстан Республикасы, 050010, Алматы қ., Гоголь к-сі, 84a

${ }^{2}$ «АЗДОРИННОВАЦИЯ» ЖШС,

Қазақстан Республикасы, 050031, Алматы қ., ш. а. Баянауыл, 1

Осы ғасырдың басында автомобиль жолдарында көлік жүктемелерінің 2-3 есе артуына байланысты ұзақ мерзімді жол конструкцияларына жаңа талаптар қойылды. Осы талаптарға сәйкес келетін наноқұрылымды асфральт-минералды және жол нано бетондарын әзірлеу бойынша іргелі, эксперименттік және практикалық зерттеулердің нәтижелері келтірілген. Көп жылдық ғылыми зерттеулер мен автомобиль жолдарының мониторинаі нәтижесінде Қазақстанда алғаш рет жоғары берік портландцементтермен салыстыру кезінде құрамында екі кальций силикаты $\left(C_{2} S\right)$ басым болатын ұзақ (баяу) қатаятын тұтқыр заттарды қолдану тиімділігі расталды. $C_{2} S$ гидратациясы кезінде нано өлшемді шамалары бар кальций C-S-H гидросиликаттары негізаі құрылым түзетін ісіктер (60\% - дан астам) болып табылады, сондықтан мұндай материалдар наноқұрылымды бетондарға жатқызылған. Жол тәжірибесінде алғаш рет автомобиль жолдарын пайдалану процесінде тиксотропия-өзін-өзі қалпына келтіру және реопексия-көліктік және температуралық жүктемелердің әсерінен қатайту қасиеттері бар наноқұрылымды асфральт-минералды және жол бетондарындағы қатаюдың коллоидтық құрылымы туралы теорияны қолданудың тиімділігі мен әділдігі расталды. Асфральт-минералды және жол бетондарының беріктігі белитті наноқұрылымды асфральт байланыстырғыш және белитті цемент тасының құрылымын жүргізілген іргелі фризика-химиялық зерттеулердің нәтижелерімен негізделген. Олардың дұрыстығы Зертханалық жағдайларда әртүрлі температурада ұзақ уақыт ұсталған бетон үлгілерін және асфральт-минералды және бетон жолдарынан бұрғыланған керндерді сынау нәтижелерімен расталады. Бетонның беріктігі 40 жылдан астам уақыт бойы күшейе түсуде. Бұл ұзаққа созылатын "Рим бетондарына" апаратын жол деп болжанады.

ТҮЙІн сөзДЕР: автомобиль жолдары, беріктік, наноқұрылымды асфральт-минералды және жол бетондары, физикалық-химиялық зерттеулер, асфральт байланыстырғыш, цемент тасы, құрылымы, фризикалық-механикалық сынақтар, беріктік. 


\section{IMPROVING THE DURABILITY OF ROADS USING NANOSTRUCTURED ASPHALT-MINERAL CONCRETES}

B.A. ASMATULAYEV'1, Doctor of Technical Sciences, Professor, Academic Advisor to the National Academy of Engineering of the Republic of Kazakhstan, Director of Science, https://orcid.org/00000001-5774-5423;

R.B. ASMATULAYEV ${ }^{2}$, candidate of Technical Sciences Director, https://orcid.org/0000-0001-5531-6641; N.B. ASMATULAYEV ${ }^{1}$, doctoral student, Master's student Chief engineer, https://orcid.org/00000001-7562-7252

${ }^{1} \mathrm{KAZSR}$ AND DI «DORTRANS» LTD,

Republic of Kazakhstan, 050010, Almaty, Gogol str. 84a

${ }^{2}$ KAZDORINNOVATION LTD,

Republic of Kazakhstan, 050031, Almaty, MD. Bayanauyl, 1

At the beginning of this century, new requirements were put forward for durable road structures, due to the increase in traffic loads on highways by 2-3 times. The results of fundamental, experimental and practical research on the development of nanostructured asphalt-mineral and road nano-concretes that meet these requirements are presented. As a result of many years of scientific research and monitoring of highways, for the first time in Kazakhstan, the effectiveness of the use of long-term (slowly) hardening binders, with a predominant content of two-calcium silicate $\left(C_{2} S\right)$, when compared with highly durable Portland cements, has been confirmed. When hydrated with $\mathrm{C}_{2} \mathrm{~S}$, the main structure-binding neoplasms (more than 60\%) are $\mathrm{C}-\mathrm{S}-\mathrm{H}$ calcium hydrosilicates, which have nano-dimensional values, so such materials are referred to as nanostructured concretes. For the first time in road practice, the effectiveness and validity of the application of the theory of the colloidal structure of hardening on road nanostructured asphalt-mineral and road concrete, which has the properties of thixotropy-self-healing and reopexy-hardening from the action of transport and temperature loads, during the operation of highways, is confirmed. The durability of asphaltmineral and road concrete is justified by the results of fundamental physical and chemical studies of the structure of belite nanostructuring asphalt binder and belite cement stone. The reliability of which is confirmed by the results of tests of concrete samples that have been sustained for a long time at various temperatures in the laboratory and cores drilled from asphalt-mineral and concrete roads. The strength of concrete continues to be strengthened for more than 40 years. It is assumed that this is the way to long-lasting "Roman concrete".

KEY WORDS: highways, durability, nanostructured asphalt-mineral and road concrete, physical and chemical studies, asphalt binder, cement stone, structure, physical and mechanical tests, strength.

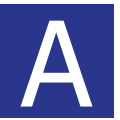

ктуальность разработки. В настоящее время в связи с изменением состава движения и повышением грузоподъемности автотранспорта до 12-13 тс на ось срок службы дорожных одежд автомобильных дорог резко сократился: покрытия из асфальтобетона - до 5-6 лет, а из цементобетона - до 25-30 лет [1-4]. В Казахстане около 100 тыс. км автомобильных дорог общего пользования, из них около 70\% дорог, на которых срочно требуется реконструкция под современные транспортные нагрузки. Значительная часть средств, выделяемая на развитие дорожной отрасли, расходуются на ежегодно возрастающие объемы ремонта и содержание устаревших дорог. Эффективность строительства автомобильных дорог из цементобетона оправдывается при сроках службы не менее 50 лет [5,6].

Теоретические предпосылки разработки. Новые концепции свидетельствуют о необходимости коренной переработки действующей до сих пор в Казахстане и России методики проектирования дорог, с учетом повышения долговечности дорог на 50 лет, для их окупаемости. 


\section{БУДУЩЕЕ НЕФТЕГАЗОВОГО КОМПЛЕКСА}

В последние годы, в связи с увеличением транспортных нагрузок, износостойкость современных асфальтобетонных покрытий значительно снизилась [1-4]. Поэтому многие исследования последних лет посвящены поиску и использованию различных полимеров и добавок в битум, для повышения качества асфальтобетона [5-7]. В то же время общеизвестно, что вяжущим в асфальтобетоне является не чисто битум, а асфальтовое вяжущее, состоящее из битума и минерального порошка [8-10]. Тонкодисперсный минеральный порошок с удельной поверхностью до 3500-4000 см²/г совместно с битумом образуют коллоидный раствор [9-11], что создает условия для тиксотропного коллоидного упрочнения асфальтобетона. Прочность чисто битумных связей в десятки раз ниже связей, образованных при совместном взаимодействии с минеральным порошком.

Известно, что коллоидная система упрочнения минеральных вяжущих [11-13] обладает свойствами длительного сохранения тиксотропии - обратимое самовосстановление после разрушений и реопексии- упрочнение при действии нагрузок.

Основные результаты исследований. Идея создания более прочного основания, чем покрытия, не нова [6-8]. О перспективах использования промышленных техногенных минеральных отходов (далее ТМО) в сочетании с цементом или цементной пылью, известью и другими активизаторами неоднократно отмечалось в работах казахстанских и российских ученых [7-9]. Ниже приводятся основные результаты исследований и испытаний дорог, подтверждающие долговечность дорожных бетонов, используемых в дорожном строительстве Казахстана уже более 43 лет.

Автомобильная дорога 1 категории «Астана - Щучинск», участок №1 07-57 км, построенная в 2007 году с цементобетонным покрытием на основании из самовосстанавливающегося золобетона, уже в течение 13 лет эксплуатируется в идеальном состоянии. В то же время остальные участки 58-212 км этой дороги с основанием их щебеночно-песчаной смеси, укрепленной 7\% портландцемента имеют деформации, требующие ремонтных работ, со второго года эксплуатации. Эффект самовосстанавливающихся бетонов объясняется за счет коренного изменения макро- и микро- структуры дорожного бетона, путем перехода от кристаллической к более тиксотропной структуре цементного камня.

В таблище 1 приведено сравнение химико-минералогических составов традиционных портландцементов (далее - алитовые цементы) и медленно твердеющих высокотехнологичных цементов (далее - белитовые цементы).

Физико-химическими исследованиями подтверждено [11], что минералогический состав белитового цементного камня преимущественно состоит из медленно твердеющих низкоосновных силикатов $\mathrm{C}_{2} \mathrm{~S}$-белит по сравнению с кристаллическими новообразованиями портландцемета. Формирования структуры медленно твердеющего цементного камня, в процессе его твердения в течение 8 лет, для наглядности показаны на фотографиях разломов цементных балочек, испытанных на растяжение при изгибе, приведенные на рисунке 1. Характер медленного разложения зерен цемента и возникновения новообразований наглядно прослеживается на фотографиях (рисунок 1). 
Таблица 1 - Химико-минералогические составы алитовых цементов и медленнотвердеющих белитовых цементов

\begin{tabular}{|c|c|c|c|c|}
\hline \multirow{2}{*}{$\begin{array}{c}\text { Виды } \\
\text { цементов }\end{array}$} & \multicolumn{4}{|c|}{ Химический состав, масс. \% } \\
\hline & $\mathrm{CaO}$ & $\mathrm{SiO}_{2}$ & $\mathrm{Al}_{2} \mathrm{O}_{3}$ & $\mathrm{Fe}_{2} \mathrm{O}_{3}$ \\
\hline Алитовый & $60-67$ & $17-25$ & $3-8$ & $0.2-6$ \\
\hline \multirow[t]{3}{*}{ Белитовый } & $33-46$ & $39-61$ & 3-10 & $3-5$ \\
\hline & \multicolumn{4}{|c|}{ Минералогический состав, масс. \% } \\
\hline & $\mathrm{C}_{3} \mathrm{~S}$ (Алит) & $\mathrm{C}_{2}$ S(Белит) & $C_{3} A$ & $\mathrm{C}_{4} \mathrm{AF}$ \\
\hline Алитовый & $40-75$ & $5-25$ & $2-15$ & $5-20$ \\
\hline Белитовый & $10-35$ & $60-85$ & $3-5$ & $2-7$ \\
\hline Примеча & ны условнь & $\begin{array}{l}\text { именования } \\
\text { алов: } \mathrm{C}_{3} \mathrm{~S}-\text { ал }\end{array}$ & $\begin{array}{l}\text { ов по } \\
\text { - бели }\end{array}$ & ающему \\
\hline
\end{tabular}

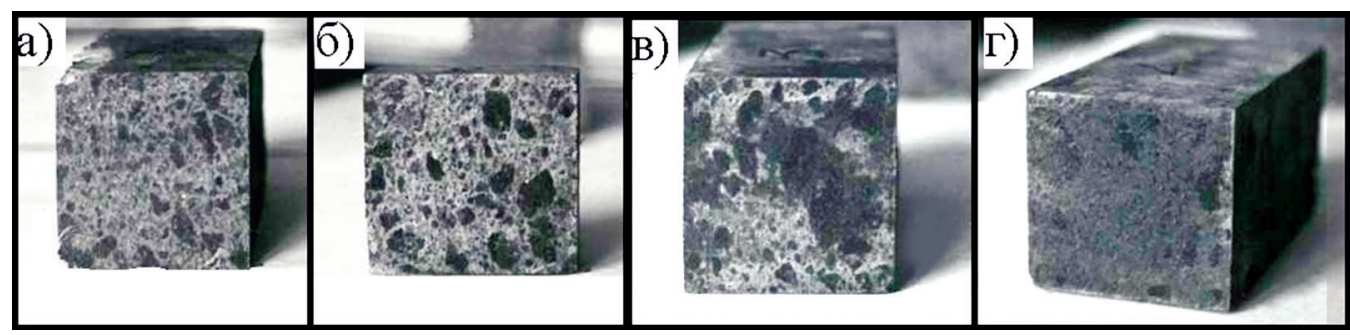

Рисунок 1 - Фотографии разломов образцов, твердевших в нормальных условиях и испытанных через: a - 1 год; 6 - 3 года; в - 6 лет; г - 8 лет

На рисунке 1 ч четко наблюдается неразложившиеся зерна цемента и зерна с образовавшейся периферийной оболочкой, которая постепенно растет (см. рисунок 16) и переходит в аморфные гелевидные новообразования (см. рисунок 1в). Аморфизм этих новообразований обуславливается нечеткостью и расплывчатостью их граней и беспорядочным их ростом во всех направлениях. Наряду с аморфитами наблюдаются единичные кристаллики $\mathrm{C}-\mathrm{S}-\mathrm{H}$ (см. риунок 1б). В имерсии гель представлен бесцветной изотропной массой с показателем светопреломления 1,330-1,567. Количество гелевидных новообразований в пробах с увеличением возраста образцов повышается. Но даже через 8 лет твердения в нормальных условиях в пробах цемента наблюдаются негидратированные зерна, что свидетельствует о потенциальной возможности цемента к дальнейшему твердению. Рентгенограммы белитового цементного камня, приведенные на рисунке 2, подтверждают полученные данные.

Таким образом, независимо от температурных режимов твердения белитового цементного камня (в пределах опыта) и сроков выдерживания, фазовый состав новообразований не претерпевает сколько-нибудь значительных изменений. 


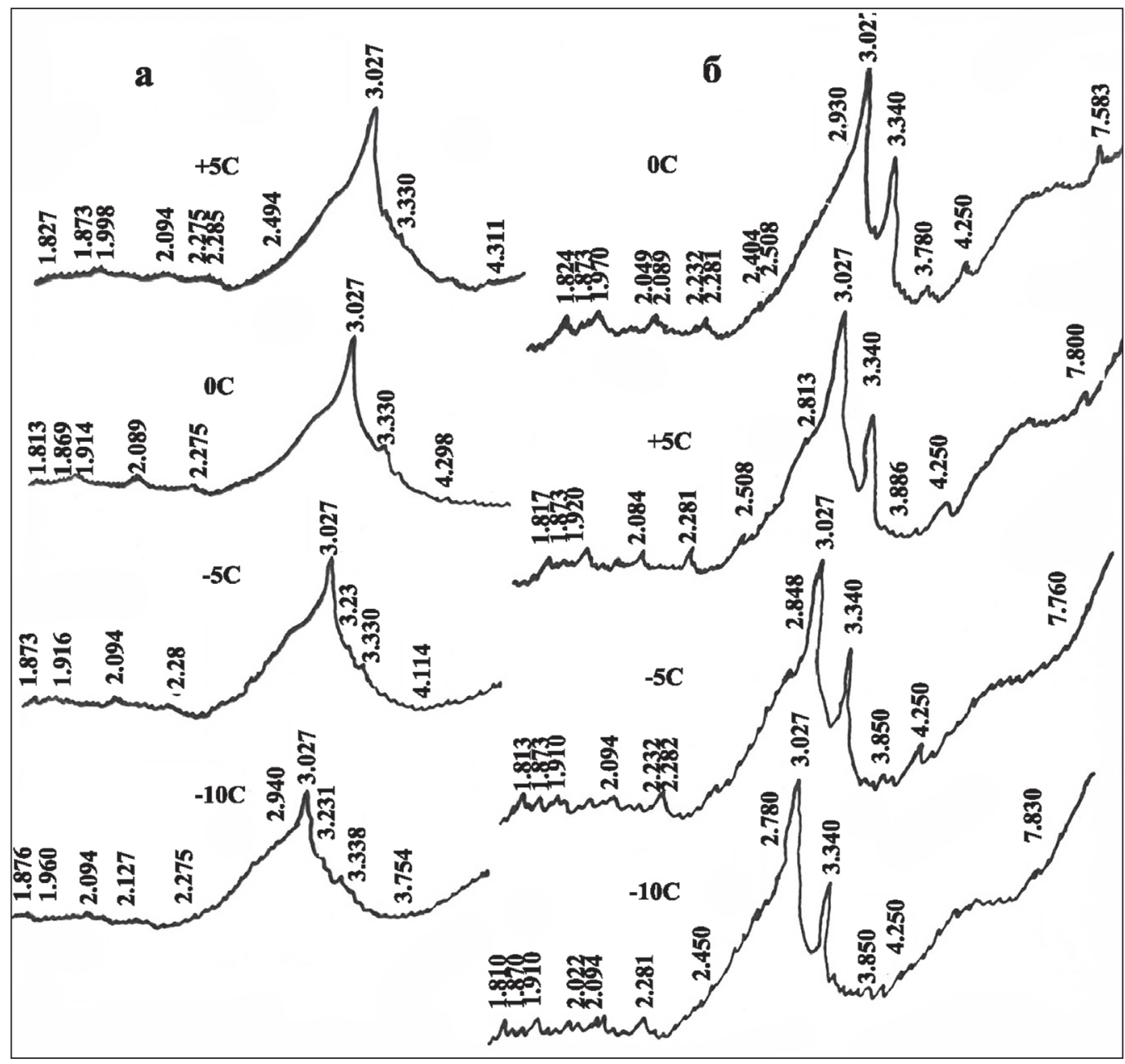

Рисунок 2 - Рентгенограммы образцов белитового цементного камня, твердевшие в течение 3-х месяцев при температурах $+5 ; 0 ;-5 ;-10^{\circ} \mathrm{C}$ : а) - после 1 месяца выдерживания в нормальных условиях; б) - без выдерживания в нормальных условиях (приведен один интервал температур)

О замедлении процессов гидратации цемента с понижением температуры твердения свидетельствует уменьшение дифракционной линии, соответствующей межплоскостному расстоянию 3,027 А, по сравнению с 3,039 А, при твердении при положительных температурах, детально описанного Х.Ф. Тейлором [12].

На рисунке 3 показаны результаты испытания ряда образцов 5, 6, 7, 8 по сравнению с образцами, постоянно твердевших в нормальных условиях.

Данные свидетельствуют, что низкие положительные и отрицательные температуры замедляют процесс твердения цемента, предварительно выдержанного в нормальных условиях. При этом, чем ниже температура твердения, тем медленнее происходит набор прочности. В таблице 2, представлены результаты испытания кернов, высверленных из бетонного основания автодороги «Фоголевка - Жданово», построенной в декабре 1977 года. 


\section{БУДУЩЕЕ НЕФТЕГАЗОВОГО КОМПЛЕКСА}

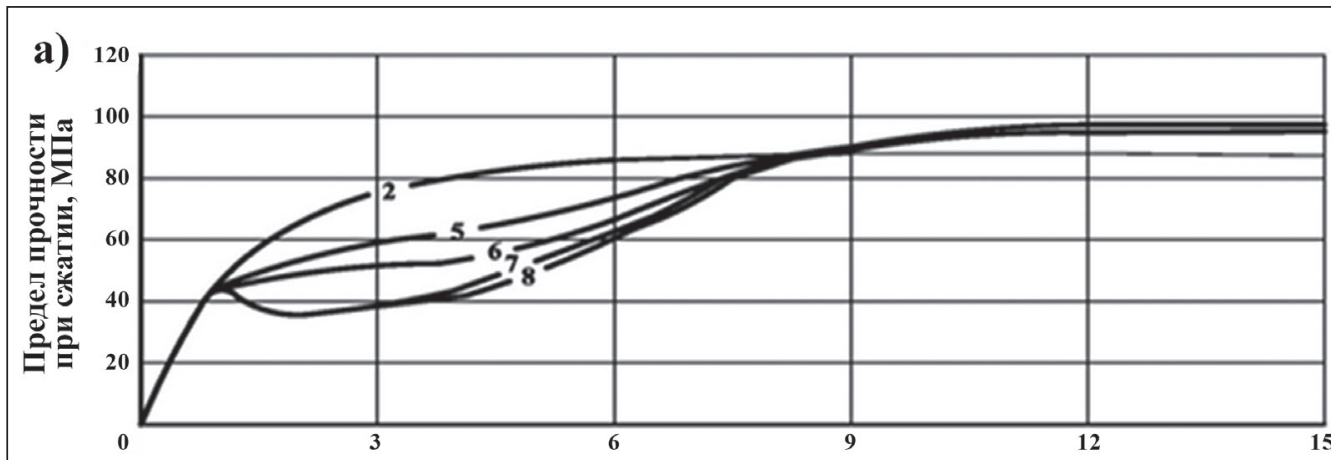

Срок твердения, месяцы

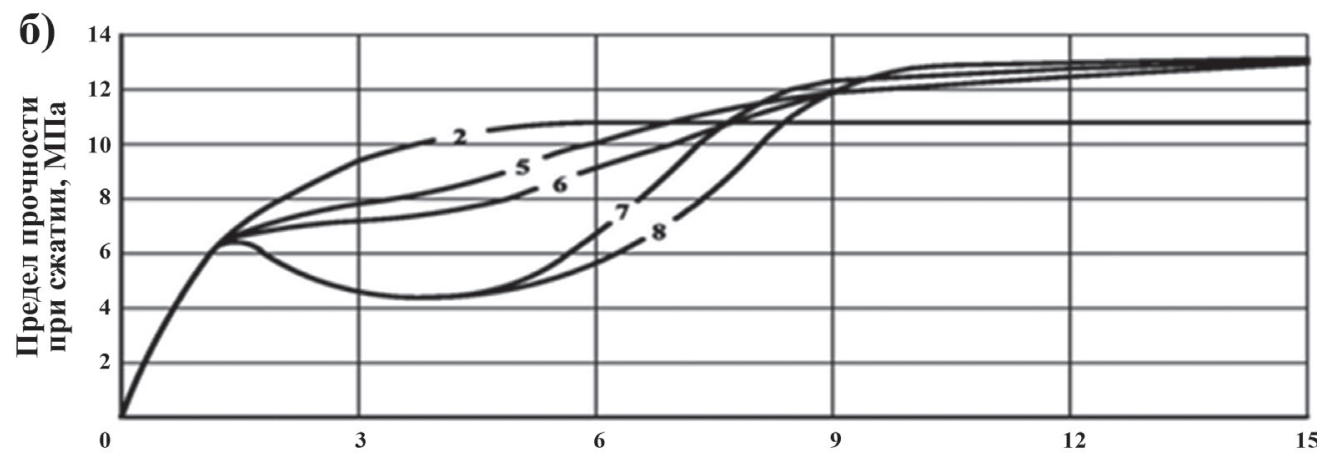

Срок твердения, месяцы

Рисунок 3 - Кинетика изменения прочности образцов белитового цементного камня во времени: 2 - постоянно в нормальных условиях;5,6,7,8 - предварительно выдержанных

1 месяц при нормальных условиях, затем соответственно при $+5^{\circ} \mathrm{C} ; 0^{\circ} \mathrm{C} ;-5^{\circ} \mathrm{C},-10^{\circ} \mathrm{C}$, затем опять в нормальных условиях: a - прочность на сжатие; 6 - прочность на растяжение при изгибе

Таблица 2 - Результаты испытания кернов из бетонного основания автодороги «Фоголевка - Жданово»

\begin{tabular}{|c|c|c|}
\hline $\begin{array}{c}\text { Наименование } \\
\text { измеряемого } \\
\text { показателя }\end{array}$ & $\begin{array}{c}\text { Испытание кернов 1989 г., } \\
\text { МПа, } \\
\text { (возраст бетона 12 лет) }\end{array}$ & $\begin{array}{c}\text { Испытание кернов 2005 г., } \\
\text { МПа, }\end{array}$ \\
\hline $\begin{array}{c}\text { Предел прочности } \\
\text { при сжатии }\end{array}$ & $\begin{array}{c}\text { (воз, } 4 ; 36,7 ; 36,5 \\
\text { Среднее 36,5 (М 350) }\end{array}$ & $\begin{array}{c}48,6 ; 49,0 ; 48,8 \\
\text { Среднее 48,8 (M 450) }\end{array}$ \\
\hline $\begin{array}{c}\text { Предел прочности } \\
\text { при изгибе }\end{array}$ & - & 8,$6 ; 8,3$ \\
\hline
\end{tabular}

Полученные нами результаты петрографического, рентгеноструктурного, дифференциально-термического анализов и наблюдения с помощью сканирующего электронного микроскопа, показали, что при твердении белитовых цементов, основными структурообразующиминовообразованиями в бетоне являются гелевидные низко основные гидросиликаты кальция типа $\mathrm{C}-\mathrm{S}-\mathrm{H}$ [11]. 
Полученные экспериментальные результаты позволяют предположить, что из всех теорий твердения минеральных вяжущих можно выделить коллоидно-химическую теорию В. Михаэлиса [12], которая, очевидно, будет более обоснованной для объяснения процессов твердения белитовых цементов.

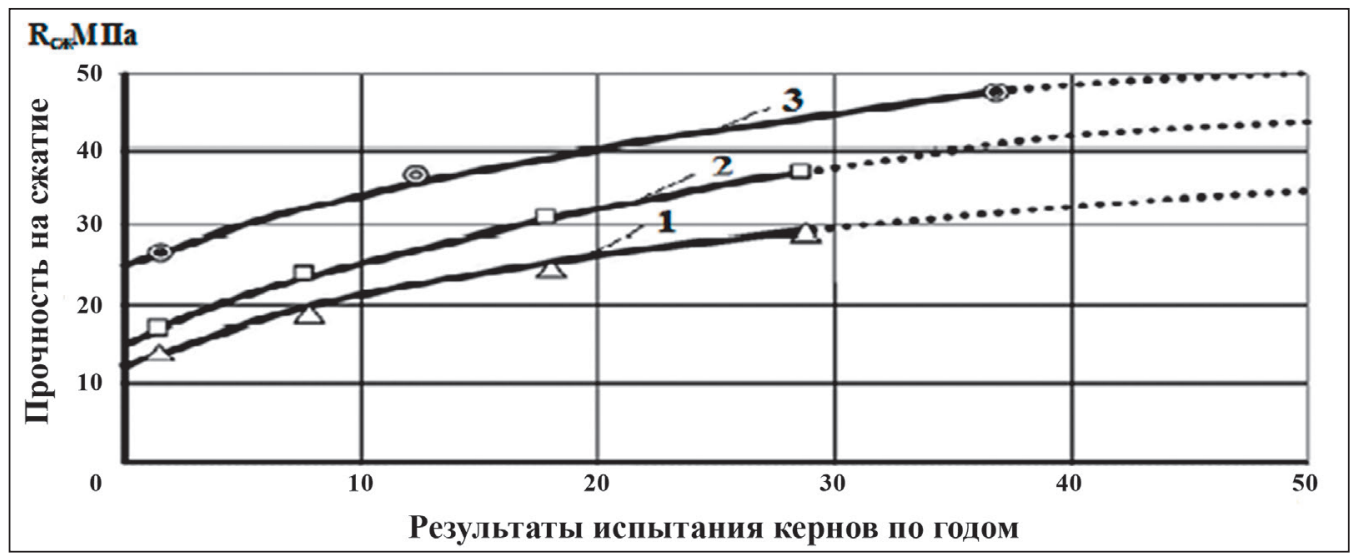

Рисунок 4 - Кинетика набора прочности самовосстанавливающихся дорожных бетонных оснований опытных участков дорог, построенных в 1976-1984 гг. 1, 2, 3 - содержание белита $\left(\mathrm{C}_{2} \mathrm{~S}\right)$ в цементах - 60; 70 и $80 \%$ соответственно

При нормальной температуре гидросиликаты C-S-H формируются в виде пластинчатых субмикрокристаллов, средняя длина которых близка к $10000 \mathrm{~A}^{0}$ (1 мкм), а ширина и толщина составляет, соответственно, $360-560 \mathrm{~A}^{0}$ и $20-30 \mathrm{~A}^{0}$. Ввиду очень малых размеров гидросиликатов, а также их способности адсорбировать на своей поверхности воду, гидросиликаты имеют свойства коллоидов. Потеря или насыщение водой сопровождается изменением расстояния между слоями кристаллической решетки гидросиликата $\mathrm{C}-\mathrm{S}-\mathrm{H}$, что приводит к изменениям прочности материала. Дальнейшее выдерживание материала во влажных условиях обеспечивает адсорбцию влаги гелем, восполнение связующих водных пленок между слоями решетки гидросиликата и восстановление прочности материала (рисунки 3, 4). Поэтому белитовые дорожные бетоны обладают свойством самовосстановления в независимости от температурно-климатических изменений и динамических транспортных нагрузок.

Основным структурообразующим компонентом в белитовом цементном камне являются низкоосновные гидросиликаты кальция $\mathrm{C}-\mathrm{S}-\mathrm{H}$, которые представляют собой аморфный клей, наноразмерных величин $[13,14]$, обладающие свойством длительной тиксотропии. Бетон - самый распространенный строительный материал, являющийся наноструктурным многофазным композитным материалом, который созревает со временем. Он состоит из аморфной фазы, кристаллов размером от нано- до микрометра и связанной воды. Свойства бетона, как и деструкционные характеристики, существуют в диапазоне (от нано- до микро- и макроуровней), когда свойства материала на каждом уровне формируются на базе свойств предыдущей ячейки меньшего размера [13-15]. Аморфная фаза гидросиликата кальция $(\mathrm{C}-\mathrm{S}-\mathrm{H})$ - это «клей», который скрепляет компоненты бетона $[16,17]$ и сам по себе является наноматериалом. В последнее время, благодаря заинтересованности в 
формировании устойчивых структур бетона $[13,18,19]$, большое внимание уделяется наноразмерной модификации структуры $\mathrm{C}-\mathrm{S}-\mathrm{H}$ для создания гибридных, органических, цементирующих нанокомпозитов. Слоистая конструкция и склонность кремниевых цепочек (кроме тетраэдрической) к структурным дефектам в $\mathrm{C}-\mathrm{S}-\mathrm{H}[13,16]$ открывают возможность для введения разнообразных органических молекул в базовую структуру C-S-H. Предложено три схемы для гибридизации или введения «гостевых молекул» в $\mathrm{C}-\mathrm{S}-\mathrm{H}$. Первая схема интерполирует органические молекулы в слой C-S-H [20].

Нами исследованы такие свойства белитовых наноцементов, как самозалечивание, с целью отработки технологии производства дорожно-строительных работ при различных температурах круглогодичного строительства и эксплуатации автомобильных дорог.

Это также подтверждается изменением количества прочносвязанной воды в цементном камне образцов, выдержанных при различных температурных режимах (рисунок 5).

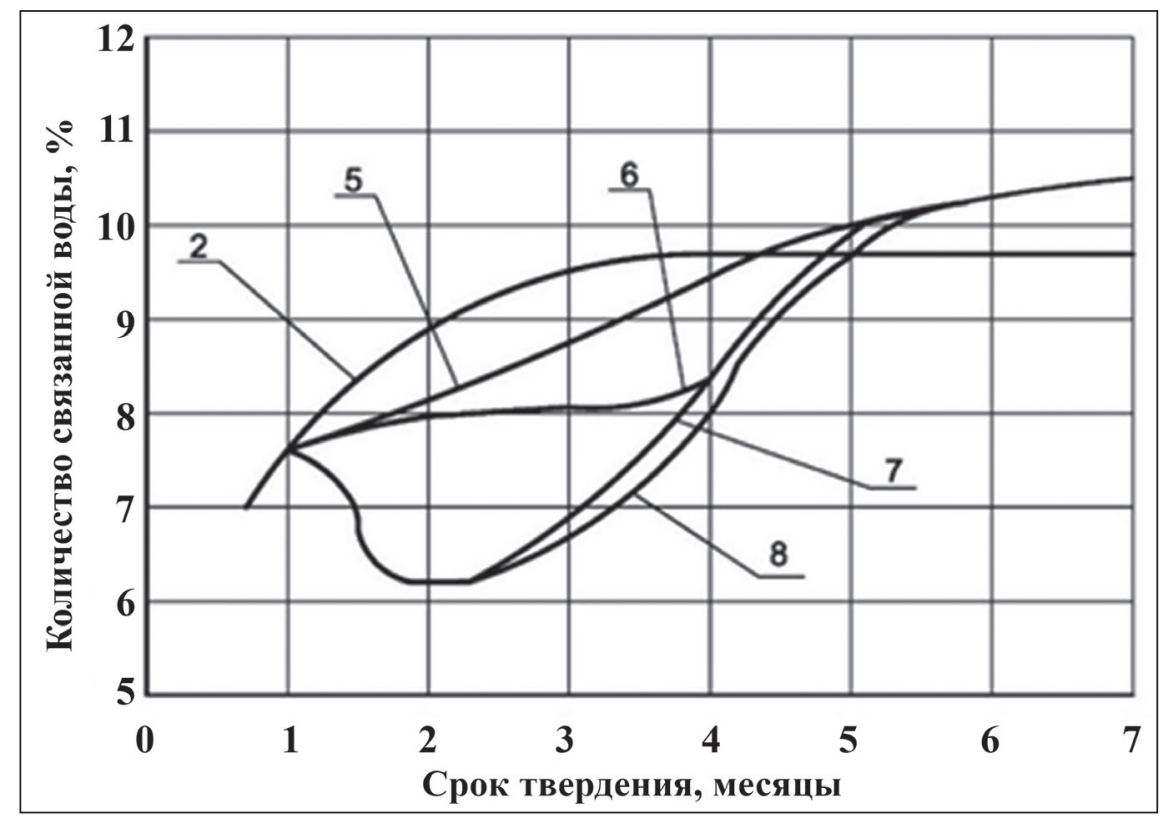

Рисунок 5 - Кинетика изменения количества прочносвязанной воды

в белитовом цементном камне в процессе твердения при различных температурах

Результаты изменения количества прочносвязанной воды в цементном камне (рисунок 5), установленного путем измерения потерь массы проб после их прокаливания при $1000^{\circ} \mathrm{C}$, предварительно выдержанных при $105^{\circ} \mathrm{C}$, подтверждают следующее. Кинетики изменений прочности (рисунок 3) и количества прочносвязанной воды (рисунок 5) цементного камня, в зависимости от температуры выдерживания проб, аналогичны, что подтверждает достоверность теоретических предпосылок о самовосставливающихся свойствах белитового цемента. При выдерживании цементного камня при низких температурах (пробы 5-8), снижение прочности (рисунок 2) 


\section{БУДУЩЕЕ НЕФТЕГАЗОВОГО КОМПЛЕКСА}

сопровождается вытеснением прочносвязанной воды (рисунок 5) из волокнистых новообразований в количестве 10-30\% от массы имеющейся влаги в их капиллярах, а при дальнейшем выдерживании при нормальных условиях их количество и прочность цементного камня восстанавливаются в течение одного месяца. Дальнейшее выдерживание при нормальных условиях в течение трех месяцев прочность и количество прочносвязанной воды превышает проб нормального твердения. Это свидетельствует об углублении процессов гидратации зерен цемента и повышении дисперсности новообразований при низких температурах выдерживания, что также повышает прочность цементного камня (рисунки 2, 3).

На рисунке 6 представлены результаты испытаний прочности различных составов дорожных бетонов в зависимости от количества белитового цемента, которые подтверждают вывод о длительном росте прочности бетонов в течение 2-х лет.

При испытании образцов бетона в возрасте 90 суток на морозостойкость было проведено до 200 циклов замораживания и оттаивания. Как видно из рисунков 8,9, происходит незначительное снижение прочностиза счет отжатия влаги из капилляров и снижения ее количества. При дальнейшем выдерживании образцов при нормальных условиях, прочность бетонов полностью восстанавливается и даже превосходит по прочности бетонов 90-суточных образцов (рисунок 7).

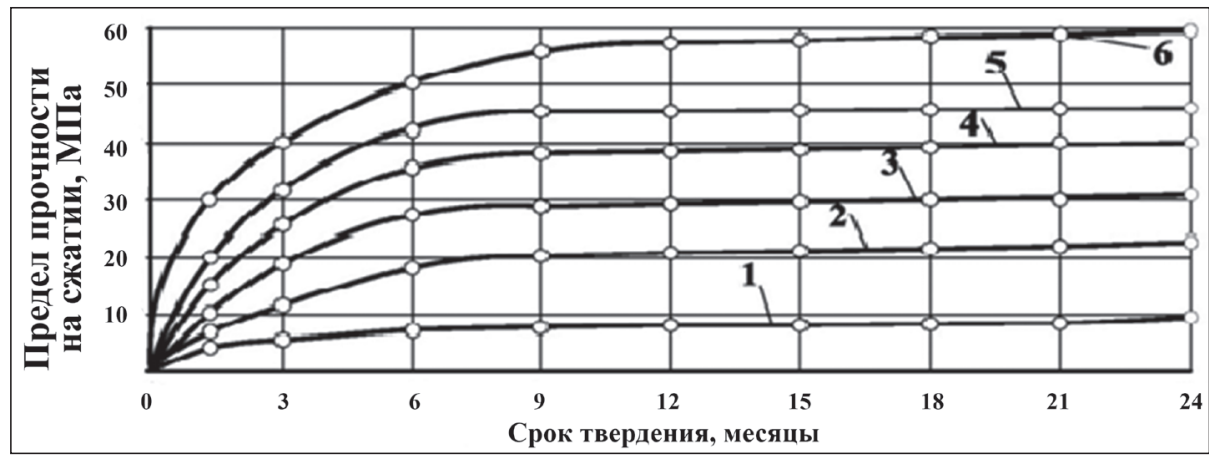

Рисунок 6 - Кинетика набора прочности дорожного бетона во времени от количества белитового цемента: 1, 2, 3, 4 5, - 10, 15, 20, 25 и 30 мас.\% цемента соответственно

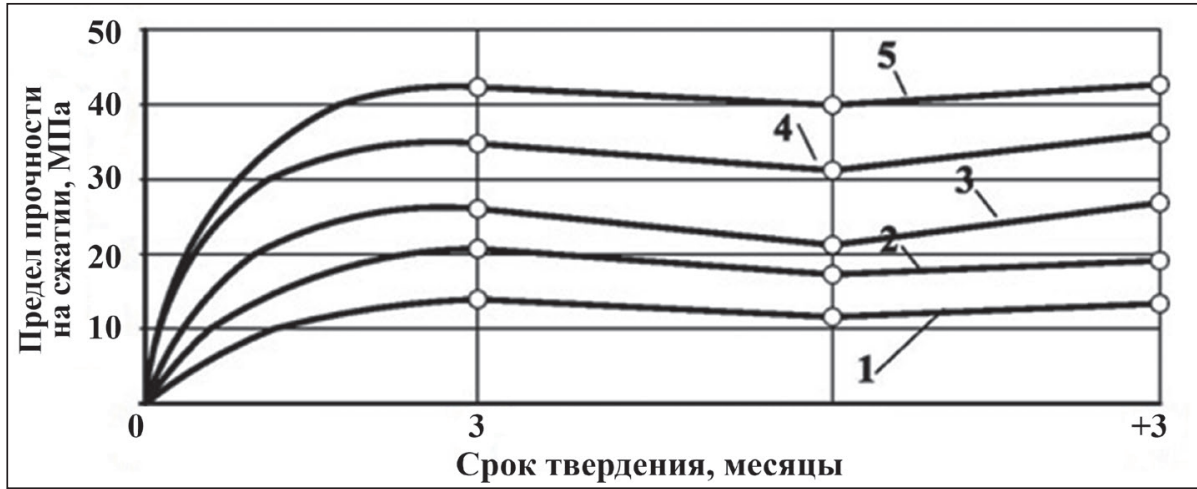

Рисунок 7 - Самовосстановление прочности дорожного бетона, испытанного на морозостойкость (MP3-200), в зависимости от количества белитового цемента:

$1,2,3,4,5-10,15,20,25$ и 30 мас.\% цемента с содержанием $\mathrm{C}_{2} \mathrm{~S}-75-80 \%$ 
Дорожные белитовые бетоны обладают медленным твердением по сравнению с традиционными алитовыми цементами, но прочностные показатели бетонов в возрасте 180 суток практически сравниваются, а деформативные показатели белитового бетона даже превышают показатели алитового бетона. При этом прочность на растяжение при изгибе на $31 \%$ выше, а модуль упругости ниже на 5000 МПа (таблица 3).

Таблица 3 - Сопоставление показателей: дорожного цементобетона и медленно твердеющего дорожного бетона на белитовом цементе

\begin{tabular}{|c|c|c|c|c|c|c|c|}
\hline \multicolumn{4}{|c|}{ Состав дорожного бетона, мас. \% } & \multirow{2}{*}{\multicolumn{3}{|c|}{$\begin{array}{c}\text { Пределы прочности в } \\
\text { возрасте } 180 \text { сут, МПа } \\
\text { (среднее значение из 3-х) }\end{array}$}} & \multirow{4}{*}{$\begin{array}{c}\text { Модуль } \\
\text { упругости } \\
\text { E }_{\text {, мпа }}\end{array}$} \\
\hline \multicolumn{2}{|c|}{$\begin{array}{c}\text { Щебень } \\
\text { фракций, мм: }\end{array}$} & \multirow{3}{*}{$\begin{array}{c}\text { Песок } \\
M_{\mathrm{kp}}=2,5\end{array}$} & \multirow{3}{*}{ Цемент,\% } & & & & \\
\hline & & & & \multirow{2}{*}{$R_{c \%}$} & \multirow[t]{2}{*}{$R_{\text {изг }}$} & \multirow[t]{2}{*}{$\mathrm{R}_{\text {изг }} / \mathrm{R}_{\text {сж }}$} & \\
\hline 5-10 & $10-20$ & & & & & & \\
\hline 15 & 34 & 29 & $\begin{array}{l}\text { Белитовый } \\
\text { цемент,15\% }\end{array}$ & 30,9 & 5,9 & 0,19 & 30000 \\
\hline 15 & 34 & 29 & $\begin{array}{l}\text { Алитовый } \\
\text { цемент, } \\
\text { М400,15\% }\end{array}$ & 30,0 & 4,5 & 0,15 & 35000 \\
\hline
\end{tabular}

Высокие деформативные свойства медленно твердеющего бетона свидетельствуют о высокой дисперсности и прочности на растяжение (когезионной связи) новообразований цементного камня белитовых цементов (рисунок 8).

Рентгенофазовые, термографические (не приведены) и электронно-микроскопические исследования, изображенные на фото (рисунок 8) подтверждают, что в таких бетонах, вышеуказанные технологические и эксплуатационные преимущества обеспечиваются, в основном, гелевидной структурой твердения белитовых цементов.
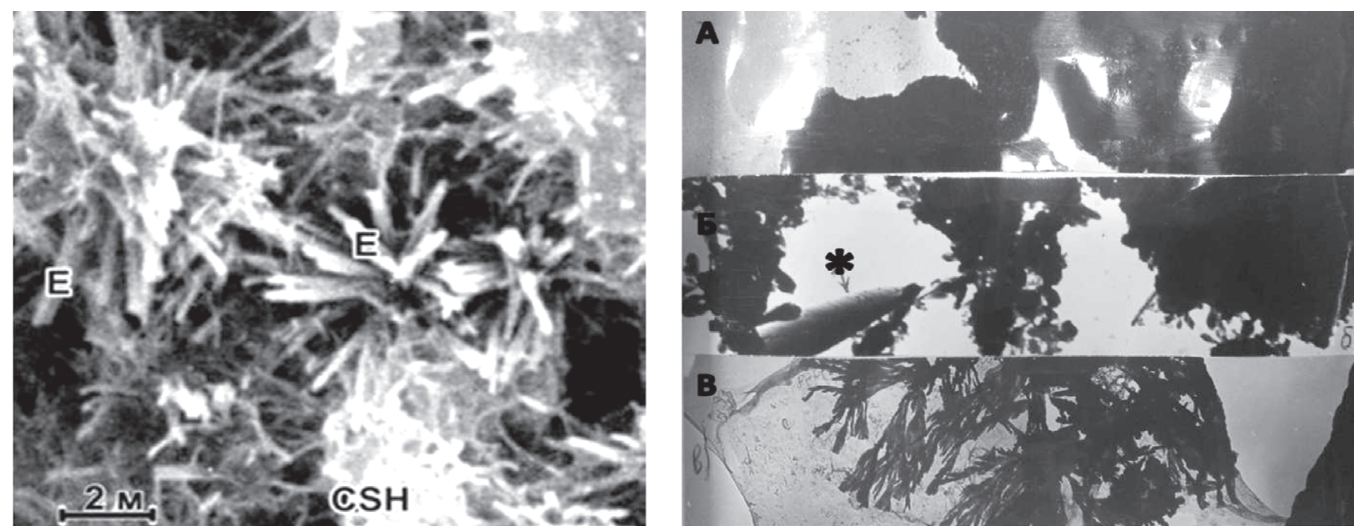

Рисунок 8 - Микроструктура цементного камня: слева - алитовый цементный камень, через 28 суток, E - кристаллы эттрингита, CSH - волокна C-S-H[11]; справа - белитовый цементный камень [12]: a - через 28 суток; б - через 90 суток, трубочка (*) C-S-H; в - через 180 суток, волокна C-S-H. (Фото электронным микроскопом - увеличение 25000) 


\section{БУДУЩЕЕ НЕФТЕГАЗОВОГО КОМПЛЕКСА}

В структуре традиционного алитового портландцементного камня, напротив, незначительное содержанием гелевидных двух кальциевых гидросиликатов, заполняют только свободное пространство внутри основного каркаса, образованного срастанием крупных кристаллогидратов.

Таблица 4 - Результаты подбора составов асфальтоминеральных смесей для монолитного дорожного основания

\begin{tabular}{|c|c|c|c|c|c|c|c|}
\hline \multirow{2}{*}{$\begin{array}{c}\text { № } \\
\text { Состава } \\
\text { смеси }\end{array}$} & $\begin{array}{c}\text { Асфальто } \\
\text { бетонный } \\
\text { гранулят }\end{array}$ & $\begin{array}{c}\text { Щебень из } \\
\text { доменного } \\
\text { шлака фр.5- } \\
\mathbf{2 0}\end{array}$ & $\begin{array}{c}\text { Щебень из } \\
\text { доменного } \\
\text { шлака фр.20-40 }\end{array}$ & $\begin{array}{c}\text { Белитовое } \\
\text { вяжущее } \\
\text { без помола }\end{array}$ & $\begin{array}{c}\text { Aктиватор } \\
\text { цемент } \\
\text { М-400 }\end{array}$ & Вода & Битум \\
\hline 1 & 40,0 & 10,0 & 30,0 & 20,0 & 2,0 & 3,0 & 2 \\
\hline 2 & 40,0 & 10,0 & 30,0 & 20,0 & 2.0 & 3,0 & 0 \\
\hline 3 & 30,0 & 20,0 & 30,0 & 20,0 & 2,0 & 3,0 & 2,0 \\
\hline 4 & 50,0 & 10,0 & 25,0 & 15,0 & 2,0 & 3,0 & 2,0 \\
\hline 5 & 50,0 & 10,0 & 25,0 & 15,0 & 2.0 & 3,0 & 0 \\
\hline 6 & 60,0 & 10,0 & 20,0 & 10,0 & 2,0 & 3,0 & 2,0 \\
\hline 7 & 70,0 & 10,0 & 15,0 & 5,0 & 2,0 & 3,0 & 2,0 \\
\hline 8 & 70,0 & 10,0 & 15,0 & 5,0 & 2.0 & 3,0 & 0 \\
\hline
\end{tabular}

Таблица 5 - Результаты испытаний образцов из асфальтоминеральных бетонов после пропаривания

\begin{tabular}{|c|c|c|c|c|}
\hline \multirow[t]{2}{*}{$\begin{array}{c}\text { № } \\
\text { Состава } \\
\text { смеси }\end{array}$} & \multirow{2}{*}{ 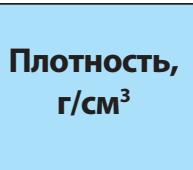 } & \multicolumn{3}{|c|}{$\begin{array}{c}\text { Прочность пропаренных образцов, } \mathbf{R}_{\text {сж' }} \text { MПа при } \\
\text { температурах }\end{array}$} \\
\hline & & $0^{\circ} \mathrm{C}$ & $20^{\circ} \mathrm{C}$ & $50^{\circ} \mathrm{C}$ \\
\hline 1 & 2,22 & 3,56 & 2,15 & 0,78 \\
\hline 2 & 2,27 & 3,52 & 3,25 & 1,47 \\
\hline 3 & 2,31 & 3,48 & 2,27 & 0,79 \\
\hline 4 & 2,25 & 3,62 & 2,27 & 0,82 \\
\hline 5 & 2,24 & 3,51 & 3,35 & 1,51 \\
\hline 6 & 2,20 & 3,62 & 3,20 & 1,44 \\
\hline 7 & 2,21 & 3,68 & 2,18 & 0,72 \\
\hline 8 & 2,31 & 3,58 & 3,39 & 1,41 \\
\hline
\end{tabular}

Таблица 6 - Прочность образцов асфальтоминеральных бетонных кернов, вырезанных из основания (различного возраста)

\begin{tabular}{|c|c|c|c|c|}
\hline \multirow{2}{*}{ Возраст образца } & \multicolumn{4}{|c|}{ Прочность на сжатие Rж, МПа при $\mathbf{~ t}^{\circ} \mathbf{C}$} \\
\cline { 2 - 5 } & $\mathbf{2 0 ^ { \circ } \mathbf { C }}$ & $\mathbf{5 0} \mathbf{C}$ & $\mathbf{0}^{\circ} \mathbf{C}$ & $\mathbf{- 1 0}^{\circ} \mathbf{C}$ \\
\hline 1 сутки & 4,81 & 2,29 & 7,4 & 7,9 \\
\hline 2 года & 9,44 & 3,32 & 12,5 & 18,6 \\
\hline 3 года & 13,15 & 4,22 & 13,8 & 22,5 \\
\hline
\end{tabular}


Результаты испытаний, приведенные в таблищах 4,5,6, показали, что введение дополнительно битума в количестве $2 \%$ является излишним; снижается прочность и на дороге появляются выделение битума. Поэтому дорога построена с использованием состава №8, с максимальным количеством асфальтового гранулята с содержанием 70\%. Прочность асфальтоминеральных бетонов, также как и асфальтобетонов, зависит от температуры испытания кернов (таблища б). Это свидетельствует о том, что в асфальт минеральном бетоне на уровне микроструктуры совместно взаимодействуют минеральное белитовое вяжущее в качестве минерального порошка и битум, содержащий в асфальтовом грануляте. Это хорошо согласуется с выводами, сделанными по органо-шлако-щелочным смесям, ранее профессором Н.В. Горелышевым [21].

Наноструктурированные асфальтоминеральные бетоны и дорожные бетоны на основе наноструктурирующих вяжущих отвечают требованиям современных концепций«вечных дорог» и «дорог с продолжительной жизнедеятельностью» США и стран ЕС, которые позволяют строить дорожные конструкции со сроком эксплуатации не менее 50 лет [22].

Инновационная концепция строительства автомобильных дорог (дорожных конструкций) предусматривает полное ресурсосбережение на всех стадиях «жизнедеятельности» автомобильной дороги: при строительстве, ремонте и реконструкции, с полной утилизацией всех материалов и повторным их использованием. По всем новым дорожно-строительным материалам и технологиям получены более 80-ти патентов Казахстана [23-32], разработаны и утверждены более 40 нормативно-технических документов, которые используются при проектировании и строительстве автомобильных дорог.

\section{ВЫВОДЫ:}

1. Самовосстанавливающиеся дорожные наноструктурированные асфальтоминеральные бетоны и дорожные бетоны обладают свойствами длительного упрочнения коллоидных структур: тиксотропии - самовосстановления и реопексии - упрочнение от действия транспортных и температурных нагрузок. Самозалечивания деструкций от температурных (отрицательных и низких положительных температур) и транспортных нагрузок, которая обуславливается некоторым временным снижением прочности, только за счет потери (отжатия) небольшого количества прочно связанной воды из капиллярной структуры бетона. С наступлением положительных температур, прочность бетона полностью восстанавливается, и, как правило, превышает первоначальную прочность.

2. Преобладающее содержание наноразмерных гидросиликатов C-S-H в белитовом асфальтоминеральном вяжущем и цементном камне, придают дорожным бетонам свойство самовосстанавливание прочности от климатических и транспортных нагрузок в процессе эксплуатации автомобильных дорог в течение более 40 лет. Установлено, что при полном механическом разрушении бетонных образцов при температуре минус 20 и повторном формовании образцов, свойство тиксотропии сохраняется до 150 измельчений образцов с набором в дальнейшем первоначальной прочности.

3. Инновационные наноструктурированные асфальтоминеральные бетоны и дорожные минеральные бетоны, полученные на основе белитовых нано- структу- 
рирующих минеральных порошков и цементов являются высокотехнологичными строительными материалами, новизна которых подтверждена рядом патентов на изобретения. Преимуществами применения нанотехнологии и наноматериалов являются следующее:

- ускоряется темп строительства бетонных дорог за счет отсутствия выдержки бетона до набора им расчетной прочности, движение по нанобетонам можно открывать непосредственно после завершения уплотнения;

- строительство дорог из холодных и теплых наноасфальтоминеральных бетонов и дорожных бетонов можно производить при низких и отрицательных температурах до минус 20 градусов;

- при производстве дорожных нанобелитовых цементов и белитовых минеральных порошков на цементных заводах, производительность заводов повысится более чем в 2 раза, так как исключается из цикла производства цементов - обжиг клинкера, стоимость которого составляет около 70\% стоимости цемента;

- широкое применение много тоннажных промышленных техногенных отложений, составляющих более 45 млрд тонн в стране, является приоритетом по действующему закону «Зеленая экономика» и будет содействовать улучшению экологии окружающей среды. Эффективность строительства и эксплуатация автомобильных дорог, с применением гидравлически активных техногенных отходов промышленности: зола-уноса ТЭС, фосфорные и доменные шлаки, бокситовые шламы, фосфогипс и повторное использование вторичных дорожно-строительных материалов и грунтов позволит повысить качество строительства, снизить себестоимость, улучшить качество окружающей среды и обеспечить экологическую безопасность дорожного строительства.

4. Из опыта США, не исключаются пути повышения долговечности цементобетонных покрытий путем корректировки минералогических составов традиционных портландцементов и увеличения количества гидросиликатов $\mathrm{C}_{2} \mathrm{~S}$, что потребует изменения требований к дорожным портландцементам и бетонам на их основе.

5. Применение дорожных конструкций с возрастающей прочностью «снизу-вверх» в соответствии с новыми концепциями потребует изменения методик проектирования и расчета дорожных одежд нежесткого и жесткого типов.

6. Широкое апробирование нанотехнологии и нано материалов предусмотрено в соответствии с научно-технической программой на 2021-2023 г.г., одобренной МИИР РК, возглавляемой Национальной инженерной академией Республики Казахстан «Разработка и внедрение эффективных экологических технологий монолитного строительства дорожно-транспортных конструкций по мировым стандартам с комплексной утилизацией промышленных техногенных отходов и вторичного сырья».

\section{ЛИТЕРАТУРА}

1 Кочетков А.В., Кокодеева Н.В., Рапопорт П.Б., Рапопорт Н.В., Шашков И.Г. Расчет и конструирование дорожных одежд // Автомобильные дороги. - 2011. - №12. - C.86-94 [Kochetkov A.V., Kokodeeva N.V., Rapoport P.B., Rapoport N.V., SHashkov I.G. Raschet i konstruirovanie dorozhnyh odezhd // Avtomobil'nye dorogi. - 2011. - №12. - S. 86-94] 
2 Паткин И.А., Пошехонова Т.А., Рогачев П.Н. К вопросу о новых методах оценки работоспособности цементобетона для дорожных и мостовых сооружений. Сборник трудов: Дороги и мосты. - М.:Росавтодор, 2011. - C.295-310 [Patkinl. A., Poshekhonova T.A., Rogachev P.N. K voprosu o novyh metodah ocenki rabotosposobnosti cementobetona dlya dorozhnyh i mostovyh sooruzhenij. Sbornik trudov: Dorogi i mosty. - M.: Rosavtodor, 2011. - S. 295-310.]

3 Ушаков В.В. Ремонт цементобетонных покрытий автомобильных дорог. Обзорная информация // Информационный центр автомобильных дорог. - 2002. - Вып. 6. C. [Ushakov V.V. Remont cementobetonnyh pokrytij avtomobil'nyh dorog. Obzornaya informaciya // Informacionnyj centr avtomobil'nyh dorog. - 2002. - Vyp. 6. - S. 28]

4 Носов В.П. Причины образования уступов на цементобетонных покрытиях автомобильных дорог // Наука и техника в дорожной отрасли. - 2008. - Вып.3. - C.23-26. [Nosov V.P. Prichiny obrazovaniya ustupov na cementobetonnyh pokrytiyah avtomobil'nyh dorog // Nauka i tekhnika v dorozhnoj otrasli. - 2008. - Vyp.3. - S. 23-26.]

5 Асматулаев Б.А., Асматулаев Р.Б., Шестаков В.Н. Теория и практика инновационных технологий в дорожном строительстве Казахстана. Материалы Международной 66-й научно-практической конференции ФГБОУ ВПО «СИБАДИ». - Омск, 2012. - С. 3338. Asmatulaev B.A., Asmatulaev R.B., Shestakov V.N. Teoriya i praktika innovacionnyh tekhnologij v dorozhnom stroitel'stve Kazahstana. Materialy Mezhdunarodnoj 66-jnauchnoprakticheskoj konferencii FGBOU VPO «SIBADI». - Omsk, 2012. - S. 33-38.

6 Радовский Б.С. Концепция вечных дорожных одежд. Каталог-справочник: Дорожная техника. - 2011. - С. 120-132 [RadovskijB.S. Koncepciya vechnyh dorozhnyh odezhd. Katalog-spravochnik: Dorozhnaya tekhnika. - 2011. - S. 120-132.]

7 Асматулаев Б.А., Шейнин А.М., Чумаченко В.И. и др. Укатываемый бетон на основе шлакового вяжущего // Автомобильные дороги. - 1993. - № 9. - C.18-20. [Asmatulaev B.A., SHejnin A.M., CHumachenko V.I. i dr. Ukatyvaemyj beton na osnove shlakovogo vyazhushchego // Avtomobil'nye dorogi. - 1993. - № 9. - S. 18-20.]

8 Исаев В.С., Еркина Н.А., Юмашев В.М., Васильев Ю.М., Саль А.О., Асматулаев Б.А. Методические рекомендации по строительству основанийи покрытий из щебеночных, гравийных и песчаных материалов, обработанных неорганическими вяжущими. - М.:Минтрансстрой СССР, Союздор НИИ, 1985. - 150 c. [Isaev V.S., Erkina N.A., YUmashev V.M., Vasil'ev YU.M., Sal' A.O., Asmatulaev B.A. Metodicheskie rekomendacii po stroitel'stvu osnovanij i pokrytij iz shchebenochnyh, gravijnyh i peschanyh materialov, obrabotannyh neorganicheskimi vyazhushchimi. - M.:Mintransstroj SSSR, SoyuzdorNII, 1985. - $150 \mathrm{s.]}$

9 Инновационный патент № 29852 РК. Самовосстанавливающийся дорожный бетон /Асматулаев Б.А. и др. Опубл. 15.05.15, бюл. № 5. Innovacionnyj patent № 29852 RK. Samovosstanavlivayushchijsya dorozhnyj beton / Asmatulaev B.A. i dr. Opubl. 15.05.15, byul. №5.

10 Радовский Б.С. Цементобетонные покрытия в США: строительство // Автомобильные дороги. - 2015. - № 4 (100). - C. 56-62. [RadovskijB.S. Cementobetonnye pokrytiya v SSHA: stroitel'stvo // Avtomobil'nye dorogi. - 2015. - № 4 (100). - S. 56-62.]

11 Тейлор Х.Ф. Гидросиликаты кальция. Химия цемента. - М.: Стройиздат,1969.- С.1718. [Tejlor H.F. Gidrosilikaty kal'ciya. Himiya cementa. - M.: Strojizdat,1969. - S.17-18.]

12 Абланов Б.Ф., Белоусов Б.В., Асматулаев Б.А. Исследование вещественного состава и кинетики твердения вяжущего на основе фосфорного шлака. Вопросы металлогении, вещественного состава и геологического строения месторождений Казахстана. - Алматы,1978, Вып. 13. - C.69-75. [Ablanov B.F., Belousov B.V., Asmatulaev B.A. Issledovanie veshchestvennogo sostava i kinetiki tverdeniya vyazhushchego na osnove 
fosfornogo shlaka. Voprosy metallogenii, veshchestvennogo sostava i geologicheskogo stroeniya mestorozhdenij Kazahstana. - Almaty, 1978, Vyp. 13. - S. 69-75.]

13 F. Sanchez, L. Zhang, C. Ince. Multi-scale performance and durability of carbon nanofiber/ cement composites [Многоуровневая работа и долговечность углеродного нановолокна/цементных композитов]. In: Bittnar Z, Bartos PJM, Nemecek J, Smilauer V, Zeman $\mathrm{J}$, editors. Nanotechnology in construction: proceedings of the NICOM3 (3rd international symposium on nanotechnology in construction). Prague, Czech Republic; 2009, p. 345-50.

14 H.M. Jennings, J.W. Bullard, J.J. Thomas, J.E. Andrade, J.J. Chen, G.W. Scherer. Characterization and modeling of pores and surfaces in cement paste: correlations to processing and properties [Определение характеристики моделирования пориповерхностей в цементном тесте: сопоставление обработки и свойств]. J Adv Concr Technol 2008; 6(1):5-29.

15 F. Sanchez, A. Borwankar. Multi-scale performance of carbon microfiber reinforced cementbased composites exposed to a decalcifying environment [Многоуровневая работа цементо-содержащих композитов, армированных углеродным микроволокном, под влиянием декальцинирующей среды]. Mater Sci Eng A 2010; 527(13- 14): 3151-8.

16 Chong K.P., Garboczi E.J. Smartand designer structural material systems [Интеллектуальные и проектирующие системы конструкционных материалов]. ProgStructMatEng 2002; 4:417-30.16.

$17 \mathrm{~K}$. Sobolev. Mechano-chemical modification of cement with high volumes of blast furnace slag [Механо-химическая модификация цемента с высоким содержанием доменного шлака]. Cem Concr Compos 2005; 27(7-8):848-53.

18 Minet J., Abramson S., Bresson B., Franceschini A., Van Damme H., Lequeux N.. Organic calcium silicate hydrate hybrids: a new approach to cement based nanocomposites [Гибриды органического гидросиликата кальция: новый подход к нанокомпозитам на основе цемента]. J Mater Chem 2006; 16:1379-83.

19 Franceschini A., Abramson S., Mancini V., Bresson B., Chassenieux C., Lequeux N.. New covalent bonded polymer-calcium silicate hydrate composites [Новые ковалентно-связанные композиты полимер-гидросиликата кальция]. J Mater Chem 2007; 17:913-22.

$20 \mathrm{H}$. Matsuyama, J.F. Young. Intercalation of polymers in calcium silicate hydrate: a new synthetic approach to biocomposites.[Введение полимеров гидросиликата кальция: новый синтетический подход к биокомпозитам.] Che m Mater 1999; 11:16-9.

21 Горелышев Н.В. Асфральтобетон и другие битумоминеральные материалы. Можайск-Терра, 1995. - С. 176. [Gorelyshev N.V. Asfal'tobeton i drugie bitumomineral'nye materialy. Mozhajsk-Terra, 1995. - S. 176.]

22 Патент № 4110 на полезную модель РК. Конструкция дорожной одежды на основе наномодифицированного бетона / Асматулаев Б.А., Асматулаев Р.Б., Чумаченко В.И., Асматулаев Н.Б., Мазгутов Р.А., Аманкосов Ж.А., Езмахунов Р.Р. Опубл. 2019. Бюл. №26. [Patent na poleznuyu model' 4110 RK. Konstrukciya dorozhnoj odezhdy na osnove nanomodificirovannogo betona / Asmatulaev B.A., Asmatulaev R.B., Chumachenko V.I., Asmatulaev N.B., Mazgutov R.A., Amankosov ZH.A., Ezmahunov R.R. Opubl. 2019. Byul. №26.]

23 Предварительный патент №16297 РК. Композиция для покрытия автомобильных дорог и аэродромов / Асматулаев Б.А., Надиров Н.К., Асматулаев Р.Б., Пшембаев М.К. и др. Опубл. 2005. Бюлл. № 10. [Predvaritel'nyj patent №16297 RK. Kompoziciya dlya pokrytiya av tomobil'nyh dorog i aerodromov / Asmatulaev B.A., Nadirov N.K., Asmatulaev R.B., Pshembaev M.K. i dr. Opubl. 2005. Byull. № 10.] 
24 Предварительный патент № 16413РК. Сероасфальтобетонная смесь / Асматулаев Б.А., Надиров Н.К., Асматулаев Р.Б., Пшембаев М.К. и др. Опубл. 2005. Бюлл. № 11. [Predvaritel'nyj patent № 16413RK. Seroasfal'tobetonnaya smes' / Asmatulaev B.A., Nadirov N.K., AsmatulaevR.B., Pshembaev M.K. idr. Opubl. 2005. Byull. № 11.]

25 Инновационный патент № 18277 РК. Способ строительства автомобильных дорог / Асматулаев Б.А., Асматулаев Р.Б., Надиров Н.К., Бакунович А.Б., Кабашев А.Р., Оспан С.А., Турманов М.Д., Сыртанов К.А. Опубл. 2010. Бюлл. № 2. [Innovacionny ipatent № 18277 RK. Sposob stroitel'stva avtomobil'nyh dorog / AsmatulaevB.A., AsmatulaevR.B., NadirovN.K., BakunovichA.B., Kabashev A.R., OspanS.A., Turmanov M.D., Syrtanov K.A. Opubl. 2010. Byull. № 2.]

26 Инновационный патент №29382 РК. Способ переработки нефтесодержащих пород и/или нефтезагрязненных материалов / Асматулаев Б.А., Асматулаев Р.Б., Надиров Н.К., Асматулаев Н.Б., Турсумуратов М.Т,, Амирханов Ж.А.Опубл. 2014. Бюл.№12. [Innovacionnyj patent №29382 RK. Sposob pererabotki neftesoderzhashchih porod i/ ili neftezagryaznennyh materialov / Asmatulaev B.A., Asmatulaev R.B., Nadirov N.K., Asmatulaev N.B., Tursumuratov M.T, , Amirhanov ZH.A. Opubl. 2014. Byul.№12.]

27 Инновационный патент № 4871 РК. Способ строительства дороги с использованием фрезерованного асфальтового гранулята / Асматулаев Б.А., Асматулаев Р.Б., Асматулаев Н.Б., Бессонов Д.В., Исламов В.А., Амирханов Ж.А. Опубл. 2020. Бюл. №16. [Innovacionnyj patent № 4871 RK. Sposob stroitel'stva dorogi s ispol'zovaniem frezerovannogo asfal'tovogo granulyata / Asmatulaev B.A., Asmatulaev R.B., Asmatulaev N.B., Bessonov D.V., Islamov V.A., Amirhanov ZH.A. Opubl. 2020. Byul. №16.]

28 Инновационный патент №2021/0271.2 РК. Наноструктурирующий минеральный порошок и наноструктурированный ассальтобетон / Асматулаев Б.А., Асматулаев Р.Б., Чумаченко В.И., Асматулаев Н.Б., Исламов В.А. Бессонов Д.В. Опубл. 2021. Бюл. №16. [Innovacionnyj patent №2021/0271.2 RK. Nanostrukturiruyushchij mineral'nyj poroshok i nanostrukturirovannyj asfal'tobeton / Asmatulaev B.A., Asmatulaev R.B., Chumachenko V.I., Asmatulaev N.B., Islamov V.A. Bessonov D.V. Opubl. 2021. Byul. №16.]

29 Инновационный патент №30948 РК. Теплая или холодная асфральтобетонная смесь (варианты) / Асматулаев Б.А., Асматулаев Р.Б., Турсумуратов М.Т., Исламов В.А., Амирханов Ж.А., Асматулаев Н.Б. Опубл. 2016. Бюл.№3. [Innovacionnyj patent №30948 RK. Teplaya ili holodnaya asfal'tobetonnaya smes' (varianty) / Asmatulaev B.A., Asmatulaev R.B., Tursumuratov M.T., Islamov V.A., Amirhanov ZH.A., Asmatulaev N.B. Opubl. 2016. Byul.№3.]

30 Асматулаев Б.А., Асматулаев Р.Б., Ордабаев А.Т., Ошанов А.Е., Езмахунов Р.Р., Касымов У.Ш. Результаты исследования технологии и опыт строительства автомобильных дорог из укатываемых шлакобетонов в зимнее время. Дороги и мосты. - M, 2017. - C.112134. [Asmatulaev B.A., Asmatulaev R.B., Ordabaev A.T., Oshanov A.E., Ezmahunov R.R., Kasymov U.Sh. Rezul'taty issledovaniya tekhnologii i opyt stroitel'stva avtomobil'nyh dorog iz ukatyvaemyh shlakobetonov v zimnee vremya. Dorogiimosty. - M, 2017. - S. 112-134.]

31 Патент на полезную модель № 3607 РК. Комплексная полимерная дисперсно-армирующая добавка / Асматулаев Б.А., Асматулаев Н.Б., Амирханов Ж.А., Бессонов Д.В. Опубл. 2018. [Patent na poleznuyu model' № 3607 RK. Kompleksnaya polimernaya dispersno-armiruyushchaya dobavka / AsmatulaevB.A., AsmatulaevN.B., AmirhanovZH.A., BessonovD.V. Opubl. 2018.]

32 Патент на полезную модель №4110 РК. Конструкция дорожной одежды на основе наномодифицированного бетона / Асматулаев Б.А., Асматулаев Р.Б., Асматулаев Н.Б., Мазгутов Р.А., Чумаченко В.И., Езмахунов Р.Р., Аманкосов Ж.А.Опубл.2019. [Patent na poleznuyumodel' № 4110 RK. Konstrukciya dorozhnoj odezhdy na osnove nanomodificirovannogo betona / Asmatulaev B.A., Asmatulaev R.B., Asmatulaev N.B., Mazgutov R.A., Chumachenko V.I., Ezmahunov R.R., Amankosov Zh.A. Opubl. 2019.] 